\title{
MOLECULAR CHARACTERIZATION OF Paecilomyces fumosoroseus (Deuteromycotina: Hyphomycetes) ISOLATES
}

\author{
Andréia Cristiane Souza Azevedo1; Márcia Cristina Furlaneto²; Daniel Ricardo Sosa-Gómez³; \\ Maria Helena Pelegrinelli Fungaro ${ }^{1 *}$ \\ ${ }^{1}$ Depto. de Biologia Geral - CCB/UEL, C.P.6001 - CEP: 86001-970 - Londrina, PR. \\ ${ }_{3}^{2}$ Depto. de Microbiologia - UEL. \\ ${ }^{3}$ Embrapa Soja - Rod. Londrina/Warta - CEP: 86001-970 - Londrina, PR. \\ *Autor correspondente <mhpfunga@carpa.ciagri.usp.br>
}

\begin{abstract}
ITS and RAPD analyses were used to investigate molecular variations within samples of Paecilomyces isolates and to resolve five morphologically atypical isolates resembling $P$. fumosorosus, obtained from whitefly in Northern Paraná State. The ITS4-ITS5 amplicon was 700 base pairs (bp) long in all isolates. The five isolates of Paecilomyces not assigned to species produced restriction profiles identical to all the reference strains of $P$. fumosoroseus. The extent of fingerprint variability observed by RAPD was sufficient to discriminate all the isolates. The genetic similarity among unidentified isolates and strains of $P$. fumosoroseus was even higher than that observed among reference strains of this species, allowing us to conclude that
\end{abstract} isolates CNPso-P77, CNPso-P78, CNPso-P80, CNPso-P85 and CNPso-P91 are P. fumosoroseus.

Key words: Paecilomyces fumosoroseus, Bemisia, RAPD, biological control, entomopathogenic fungus

\section{CARACTERIZAÇÃO MOLECULAR DE ISOLADOS DE Paecilomyces fumosoroseus (Deuteromycotina: Hyphomycetes)}

\begin{abstract}
RESUMO: As análises de RAPD (Polimorfismo de DNA Amplificado ao Acaso) e ITS (Sequências Internas Transcritas) foram utilizadas para investigar a variabilidade molecular entre isolados de Paecilomyces e para identificar cinco isolados morfologicamente atípicos, obtidos a partir de mosca branca no Norte do Estado do Paraná, que possuíam alguma semelhança com $P$. fumosoroseus. $O$ produto da amplificação com os primers ITS4 e ITS5 apresentou 700 pares de bases para todos os isolados investigados. Os cinco isolados não identificados deram origem a padrões de restrição idênticos a todas as linhagens de $P$. fumosoroseus utilizadas como referência. A variabilidade observada nos perfis de RAPD foi suficiente para discriminar todos os isolados. A similaridade genética entre os isolados não identificados e as linhagens de $P$. fumosoroseus foi maior do que aquela observada entre as linhagens referência desta espécie. Este fato permitiu concluir que os isolados CNPso-P77, CNPso-P78, CNPso-P80, CNPso-P85 and CNPso-P91 pertencem à espécie P. fumosoroseus. Palavras-chave: Paecilomyces fumosoroseus, Bemisia, RAPD, controle biológico, fungo entomopatogênico
\end{abstract}

\section{INTRODUCTION}

The whitefly Bemisia argentifolli is one of the most severe agricultural pests of the $20^{\text {th }}$ century. It is widespread throughout the world, and causes considerable damage to a variety of high value crops, including in Brazil where $B$. argentifolli was recently introduced. As chemical controls were shown to be ineffective, efforts have been made to develop natural remediation in applying biological controls of this pest. Over the world, one of the most common sources of whitefly population mortality is a mycosis caused by the entomopathogenic fungus Paecilomyces fumosoroseus (Wise) Brawn \& Smith (Lacey et al., 1996; Humber, 1992). This fungus is associated with whitefly in different regions of the globe (Lacey et al., 1996), including observations performed in Brazil on soybean and other vegetables. The pathogenicity of $P$. fumosoroseus against whitefly has recently been studied (Vidal et al., 1997; Wraight, et al., 1998).

Despite common outbreaks of $B$. argentifolli, little is known about the genetic variability of its potential nemesis, $P$. fumosoroseus. The detection of variability and knowledge of various strain identities are basic prerequisities for either the development of an effective biocontrol strategy or to evaluate the impact of artificial epizootics. The morphological characteristics used for classification of Paecilomyces species frequently do not resolve new isolates into clearly defined species and provide no isolate-level characterisation. Currently, more sensitive genetic methods such as random amplification of polymorphic DNA (RAPD) (Williams et al., 1990) and nuclear rDNA analysis have been extensively employed for genetic variability analyses (Fungaro \& Vieira, 1998) and for the identification of species and isolates including entomopathogenic fungi (Fegan et al., 1993; Leal et al., 1994, Bidochka et al, 1994; Tigano-Milani et al., 1995a; Tigano-Milani et al., 1995b; Fungaro et al., 1996; Cravanzola et al., 1997; Berretta et al., 1998, Cantone \& Vandenberg, 1998; Piatti et al. 1998).

In this study polymorphisms of internal transcribed spacers (ITS) of ribosomal DNA amplified by polymerase chain reaction (PCR) and RAPD were used to investigate 
molecular variations of Paecilomyces isolates and to resolve five morphologically atypical isolates resembling $P$. fumosoroseus, obtained from whitefly in Northern Paraná State (Sosa-Gómez, 1998).

\section{MATERIAL AND METHODS}

\section{Fungal Isolates}

ITS-rDNA and RAPD analyses were performed on five unidentified Paecilomyces isolates (CNPso-P77, CNPsoP78, CNPso-P80, CNPso-P81, and CNPso-P85) obtained from infected $B$. argentofolli in northern regions of Paraná State, Brazil, and seven strains of $P$. fumosoroseus from different hosts and geographic regions (CNPso-P92, CNPsoP93, ARSEF2658, ARSEF 3083, ARSEF3303, ARSEF3660, ARSEF3699) (TABLE 1). In addition, five isolates of $P$. tenuipes were used as an outgroup.

\section{DNA isolation}

Conidial suspensions of 17 isolates in complete medium (Pontecorvo et al., 1953), were incubated for 2 days under agitation at $28^{\circ} \mathrm{C}$. The resulting mycelium was harvested by filtration. To extract the DNA, $1 \mathrm{~g}$ of mycelium was ground to a fine powder in liquid nitrogen and incubated in $800 \mu \mathrm{L}$ DNA extraction buffer $(100 \mathrm{mM}$ Tris$\mathrm{HCl}(\mathrm{pH} 8.0), 25 \mathrm{mM}$ EDTA, $1 \% \mathrm{SDS}, 25 \mathrm{mM} \mathrm{NaCl})$ at $65^{\circ} \mathrm{C}$ for $20 \mathrm{~min}$. The suspension was deproteinized by extracting once with an equal volume of phenol and once with an equal volume of chloroform: isoamyalcohol (24:1). DNA was precipitated by adding two volumes of ice-cold ethanol and $10 \% 3 \mathrm{M}$ sodium acetate. The precipitate was collected by centrifugation, washed with $70 \%$ ethanol and dried. The pellet was resuspended in TE (10mM Tris, $1 \mathrm{mM}$ EDTA pH 8.0).

\section{rDNA ITS Regions Analyses}

Primers ITS4 (5'TCCTCCGCTTATTGATATGC-3') and ITS5 (5'GGAAGTAAAAGTCGTAACAAGG-3') were used to amplify the ITS region of rDNA. The $50 \mu \mathrm{L}$ of reaction mixture contained $10 \mathrm{ng}$ template DNA, $1 \mu \mathrm{M}$ of each primer, $100 \mu \mathrm{M}$ of each dNTP, $5 \mu \mathrm{L} 10 \mathrm{x}$ PCR buffer, $1.5 \mathrm{mM} \mathrm{MgCl}$, and 2.5 Units of Taq Polymerase. The mixture was subjected to amplification in a MJ Research thermal cycler. An initial denaturation step of 2 min at $95^{\circ} \mathrm{C}$ was followed by 35 cycles of annealing for $1 \mathrm{~min}$ at $55^{\circ} \mathrm{C}$, extension for $1 \mathrm{~min}$ at $72^{\circ} \mathrm{C}$ and denaturation for $2 \mathrm{~min}$ at $95^{\circ} \mathrm{C}$ before a final extension step of $5 \mathrm{~min}$ at $72^{\circ} \mathrm{C}$. The resultant reaction mixture $(10 \mu \mathrm{L})$ was separated on a $1.4 \%$ horizontal agarose gel, stained with ethidium bromide and visualised under UV illumination. For restriction analysis, $10 \mu \mathrm{L}$ of each PCR product was digested in a $20 \mu \mathrm{L}$ volume, using Alul, Xho I, Dde I, Bam H1, Pst I, Pvu I, Hind III, Ras II, Sau 3A1, Eco RI, Hae III under conditions supplied by the manufacturer (Gibco-BRL). The restriction reactions were separated by electrophoresis in $1.4 \%$ agarose gels. After staining, the gels were photographed over a UV transilluminator.
TABLE 1 - Origin of Paecilomyces isolates.

\begin{tabular}{|c|c|c|c|}
\hline Isolates & & Host & Location \\
\hline $\begin{array}{l}\text { CNPSO-P77 } \\
\text { (ARSEF 5154) }\end{array}$ & $\begin{array}{l}\text { Paecilomyces } \\
\text { sp. }\end{array}$ & \multicolumn{2}{|c|}{ B. argentifoliiPR/Brazil } \\
\hline $\begin{array}{l}\text { CNPSo-P78 } \\
\text { (ARSEF 5155) }\end{array}$ & $\begin{array}{l}\text { Paecilomyces } \\
\text { sp. }\end{array}$ & \multicolumn{2}{|c|}{ B. argentifoliiPR/Brazil } \\
\hline $\begin{array}{l}\text { CNPSo-P80 } \\
\text { (ARSEF 5157) }\end{array}$ & $\begin{array}{l}\text { Paecilomyces } \\
\text { sp. }\end{array}$ & \multicolumn{2}{|c|}{ B. argentifoliiPR/Brazil } \\
\hline $\begin{array}{l}\text { CNPSo-P81 } \\
\text { (ARSEF 5158) }\end{array}$ & $\begin{array}{l}\text { Paecilomyces } \\
\text { sp. }\end{array}$ & \multicolumn{2}{|c|}{ B. argentifolii PR/Brazil } \\
\hline CNPSo-P85 & $\begin{array}{l}\text { Paecilomyces } \\
\text { sp. }\end{array}$ & \multicolumn{2}{|c|}{ B. argentifoliiPR/Brazil } \\
\hline $\begin{array}{l}\text { CNPSo-P92 } \\
\text { (ARSEF 3638) }\end{array}$ & $\begin{array}{l}P . \\
\text { fumosoroseus }\end{array}$ & Soil & PR/Brazil \\
\hline $\begin{array}{l}\text { CNPSo-P93 } \\
\text { (ARSEF 2956) }\end{array}$ & $\begin{array}{l}P . \\
\text { fumosoroseus }\end{array}$ & $\begin{array}{l}\text { Spaethiella } \\
\text { sp. }\end{array}$ & AM/Brazil \\
\hline ARSEF-2658 & $\begin{array}{l}P . \\
\text { fumosoroseus }\end{array}$ & $\begin{array}{l}\text { Trialeurodes } \\
\text { vaporariorum }\end{array}$ & USA \\
\hline ARSEF-3083 & $\begin{array}{l}P . \\
\text { fumosoroseus }\end{array}$ & B. tabaci & USA \\
\hline ARSEF-3303 & $\begin{array}{l}P . \\
\text { fumosoroseus }\end{array}$ & Bemisia sp. & Mexico \\
\hline ARSEF-3660 & $\begin{array}{l}P . \\
\text { fumosoroseus }\end{array}$ & B. tabaci & USA \\
\hline ARSEF- 3699 & $\begin{array}{l}P . \\
\text { fumosoroseus }\end{array}$ & B. tabaci & India \\
\hline CNPso-P95 & $P$. tenuipes & Noctuidae & PR/ Brazil \\
\hline CNPso-P96 & $P$. tenuipes & Noctuidae & PR/Brazil \\
\hline CNPso-P41 & $P$. tenuipes & $\begin{array}{l}\text { pupa of } \\
\text { lepidopteran }\end{array}$ & PR/Brazil \\
\hline CNPso-42 & $P$. tenuipes & $\begin{array}{l}\text { pupa of } \\
\text { lepidopteran }\end{array}$ & PR/Brazil \\
\hline ARSEF-2488 & $P$. tenuipes & $\begin{array}{l}\text { Spodoptera } \\
\text { frugiperda }\end{array}$ & Mexico \\
\hline
\end{tabular}

\section{RAPD Analyses}

The 10-mers used as the random primer in the RAPD procedure was purchased from Operon Technologies, Alameda, CA. Taq DNA polymerase and DNA polymerisation mix (dNTP) were supplied by Pharmacia. The 10x concentrated buffer, supplied with the enzyme, contained $100 \mathrm{mM}$ Tris- $\mathrm{HCl}$ pH 9.0, $500 \mathrm{mM} \mathrm{KCl}$, $15 \mathrm{mM} \mathrm{MgCl}_{2}$. The amplification reactions were conducted in a total volume of $25 \mu \mathrm{L}$. The mixture contained $8.8 \mu \mathrm{l}$ of fresh ultra-pure sterile water, $2.5 \mu \mathrm{l}$ buffer, $4.0 \mu \mathrm{L}$ of dNTP (200 $\mu \mathrm{M}$ each), $2.5 \mu \mathrm{L}$ of primer $(2,5 \mathrm{mM}), 0.3 \mu \mathrm{L}$ of enzyme (1.5 units), $3.0 \mu \mathrm{L}$ of $\mathrm{MgCl}_{2}(12.5 \mathrm{mM})$ and $4.0 \mu \mathrm{L}$ of DNA (20-25 ng). The final concentration of magnesium in the reaction was $3.0 \mathrm{mM}$. Control reactions were run containing all components except genomic DNA and none of the primers employed yielded detectable amplified products. The mixture was subjected to the following temperature conditions: $92^{\circ} \mathrm{C}$ for $5 \mathrm{~min}$, followed by 40 cycles of $92^{\circ} \mathrm{C}$ for $45 \mathrm{sec}, 39^{\circ} \mathrm{C}$ for $1 \mathrm{~min} 30 \mathrm{sec}, 72^{\circ} \mathrm{C}$ for 2 min and ending with $3 \mathrm{~min}$ at $72^{\circ} \mathrm{C}$. Samples of $22 \mu \mathrm{L}$ of the RAPD products were assayed by electrophoresis in $1.4 \%$ agarose gels run with TBE buffer. Electrophoresis 
was conducted at $3 \mathrm{~V} / \mathrm{cm}$. Gels were stained with ethidium bromide and photographed under UV using a Pan F llford film. For data analysis, each isolate was scored for the presence or absence of amplification products. The data were entered into a binary matrix and a pairwise similarity matrix was constructed using the Sorensen coefficient (Sneath \& Sokal, 1973). An UPGMA cluster based on Sorensen values was generated using the NTSYS (Numerical Taxonomy System, Applied Biostatistics, Setauket, New York) computer programme (Rohlf, 1994).

\section{RESULTS AND DISCUSSION}

The development of PCR and the design of primers for the amplification of the various rDNA regions have considerably facilitated taxonomic studies of fungi. ITS sequences are generally constant, or show little variation within species but vary between species in a particular genus. As such, these sequences have been widely used to develop rapid procedures for the identification of fungal species by PCR-RFLP analysis (Edel, 1998). In this study ITS analyses were conducted by restriction enzyme digestion of the amplified region using the primers ITS 4 and ITS 5. The ITS4-ITS5 amplicon was 700 base pairs (bp) long in all isolates of Paecilomyces sp., $P$. fumosoroseus and $P$. tenuipes. Of the 12 restriction enzymes used, differences between isolates were detected with Hae III only. No restriction sites were found when DNA was treated with Alul, Xho I, Dde I, Bam H1, Pst I, Pvu I and Hind III. The enzymes Ras II, Sau 3A1, Eco RI digested the amplicon, but showed no polymorphisms among isolates. Interspecific polymorphisms detected with Hae III, discriminated $P$. fumosoroseus from $P$. tenuipes (Figure 1).

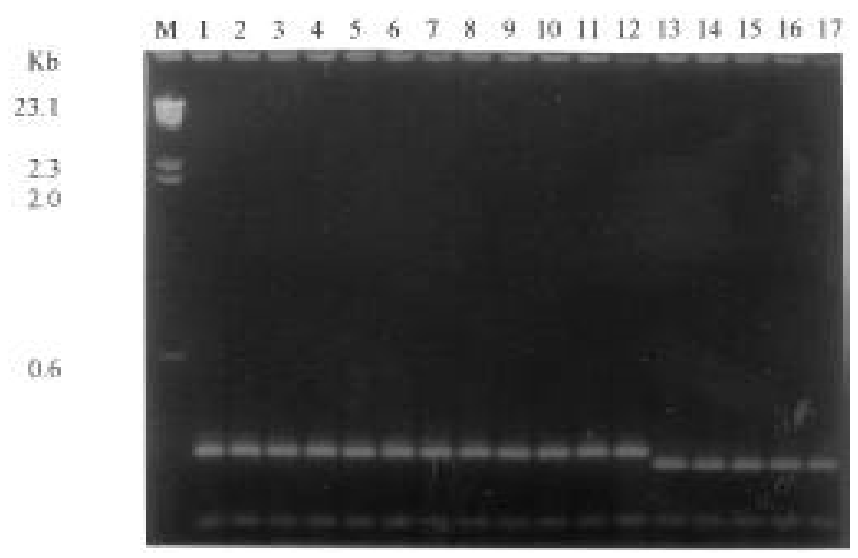

Figure 1 - ITS-RFLP patterns of Paecilomyces isolates using HaellI restriction enzyme. Lane 1, $P$. fumosoroseus ARSEF 3303; lane 2-6, Paecilomyces sp. CNPso-81, CNPso-77, CNPso78, CNPso-P80, CNPso-P85, respectively; lane 7-12, Paecilomyces fumosoroseus ARSEF 3699, ARSEF 3083, CNPso-92, CNPso-P93, ARSEF 3660, ARSEF 2658, respectively; lane 13-17, Paecilomyces tenuipes CNPso95, CNPso-96, ARSEF 2488, CNPso-41, CNPso-42, respectively. The lane marked with the letter $\mathrm{M}$ is IHind III molecular mass standards. Molecular sizes in Kilobases are indicated on the right.
The five isolates of Paecilomyces not assigned to species produced restriction profiles identical to all the reference strains of $P$. fumosoroseus. In addition, ITS intraspecific polymorphisms were observed for neither $P$. tenuipes nor P. fumosoroseus.

RAPD analyses using 31 primers produced 536 scored bands within all of the 17 isolates. An example of a typical RAPD pattern is given in Figure 2. The extent of fingerprint variability was sufficient to discriminate all isolates. This feature is very important because the identification of isolates of Paecilomyces, has often turned out to be difficult or even impossible when based solely on morphological traits.

A dendrogram based on the amplification fragments is shown in Figure 3. The isolates were separated into 2 large phenetic groups. The first group is formed by all isolates of $P$. fumosoroseus and the five unidentified isolates. The second group includes all isolates of $P$. tenuipes. Despite the high genetic divergence between these two groups (0.75), a common amplification product obtained using the primer OPAK-16 (Figure 2) was observed for all isolates. The five unidentified isolates CNPso-P77, CNPso-P78, CNPso-P80, CNPso-P85 and CNPso-P91 were very similar to each other, with an average pairwise similarity of $92.5 \%$. This high genetic similarity was expected since they were isolated from the same epizootic phase in northern regions of Paraná State. The genetic similarity among the unidentified isolates and strains of $P$. fumosoroseus was even higher than that observed among reference strains of this species. These data allow us to conclude that isolates CNPso-P77, CNPso-P78, CNPso-P80, CNPsoP85 and CNPso-P91 are P. fumosoroseus. A similar strategy was employed by Tigano-Milano et al. (1995b) to study 27 P. fumosoroseus isolates, of which 15 were obtained from $B$. tabaci, in comparison with one strain of $P$. lilacinus and nine strains of Paecilomyces not assigned to species.

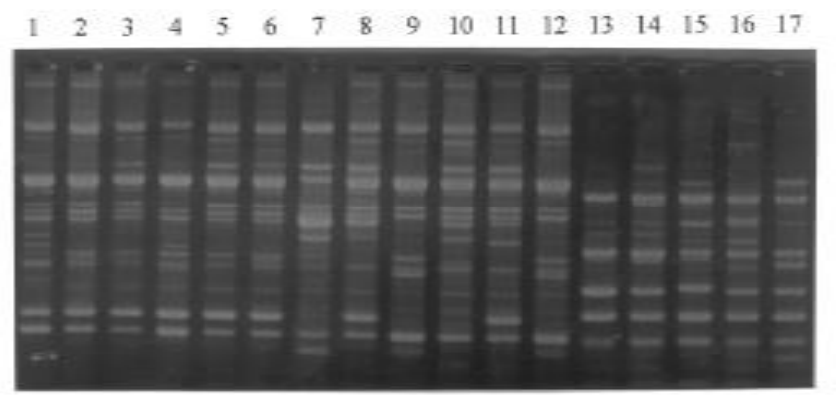

Figure 2 - RAPD profile obtained with primer OPAK-16. Lane 1, $P$. fumosoroseus ARSEF 3303; lane 2-6, Paecilomyces sp. CNPso-81, CNPso-77, CNPso-78, CNPso-P80, CNPsoP85, respectively; lane 7-12, Paecilomyces fumosoroseus ARSEF 3699, ARSEF 3083, CNPso-92, CNPso-P93, ARSEF 3660, ARSEF 2658, respectively; lane 13-17, Paecilomyces tenuipes CNPso-95, CNPso-96, ARSEF 2488, CNPso-41, CNPso-42, respectively. 


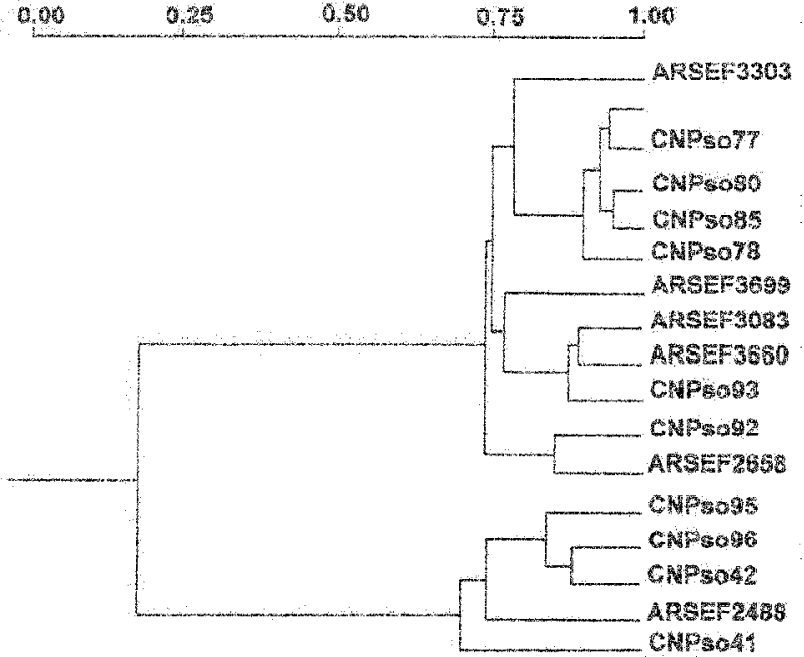

Figure 3 - Dendrogram constructed from analysis of DNA fragments of 7 Paecilomyces fumosoroseus, 5 Paecilomyces $\mathrm{sp}$. and 5 Paecilomyces tenuipes isolates amplified by RAPD. The matrix was created with the Sorensen similarity coefficient, and clustering was performed with UPGMA. The scale on top indicates \% similarity.

\section{ACKNOWLEDGMENTS}

This investigation was supported by PRONEX. The CNPq scholarship was greatly appreciated by ACSA.

\section{REFERENCES}

BERRETTA, M.F.; LECUONA, R. E.; ZANDOMENI, R. O.; GRAU, $O$. Genotyping isolates of the entomopathogenic fungus Beauveria bassiana by RAPD with fluorescent labels. Journal of Invertebrate Pathology, v.71, p.145-150, 1998.

BIDOCHKA, M.J.; MCDONALD, M.A.; ST. LEGER, R.J.; ROBERTS, D.W. Differentiation of species and strains of entomopathogenic fungi by random amplified polymorphic DNA (RAPD). Current Genetics, v.25, p.107-113, 1994.

CANTONE, F.A.; VANDENBERG, J.D. Intraspecific diversity in Paecilomyces fumosoroseus. Mycological Research, v.102, 801-806, 1998.

CRAVANZOLA, F.; PIATTI, P.; BRIDGE, P.D.; OZINO, O.I. Detection of genetic polymorphism by RAPD-PCR in strains of the entomopathogenic fungus Beauveria brongniartii isolated from European cockchafer (Melolontha spp.). Letters in Applied Microbiology, v.25, p.289-294, 1997.

EDEL, V. Polymerase Chain Reaction in Mycology: an Overview. In: BRIDGE,. P.D., ARORA, D.K., REDDY, C.A.; ELANDER, R.P. (Ed.) Applications of PCR in Mycology. Cambridge: University Press, 1998. p.1-20.

FEGAN, M.; MANNERS, J.M.; MACLEAN, D.J.; IRWIM, J.A.G.; SAMUELS, K.D.Z.; HOLDOM, D.G.; LI, D.P. Random amplified polymorphic DNA markers several a high degree of genetic diversity in the entomopathogenic fungus Metarhizium anisopliae var. anisopliae. Journal of General Microbiology, v.139, p.2075-2081, 1993.

FUNGARO, M.H.P.; VIEIRA, M.L.C.; PIZZIRANI-KLEINER, A.A.; AZEVEDO, J.L. Diversity among soil and insect isolates of Metarhizium anisopliae var. anisopliae detected by RAPD. Letters in Applied Microbioogy, v.22, p.389-392, 1996.
FUNGARO, M. H. P.; VIEIRA, M. L. C. Aplicações da PCR em Ecologia Molecular. In: MELO, I.S., de AZEVEDO, J. L. (Ed.) Ecologia Microbiana. Jaguariúna: Embrapa, CNPMA, 1998. p.205-227.

HUMBER, R.A. Collection of Entomopathogenic cultures: ARSEF catalog of strains. Ithaca, 1992. (USDA, ARS Publication, 110). Update in http://www.ppru.cornell.edu/ mycology/Insect_mycology.html

LACEY, L.A.; FRANSEN, J.J.; CARRUTHERS, R. Global distribution of naturally occurring fungi of Bemisia, their biologies and use as biological control agents. In: GERLING, D.; MAYER, R. (Ed.) Bemisia 1995: taxonomy, biology, damage, and management. Andover: Intercept, 1996.

LEAL, S.C.M.; BERTIOLI, D.J.; BUTT, T.M.; PEBERDY, J.F. Characterization of isolates of the entomopathogenic fungus Metarhizium anisopliae by RAPD-PCR. Mycological Research, v.98, p.1077-1081, 1994.

PIATTI, F.; CRAVANZOLA, F.; BRIDGE, P.D.; OZINO, O.I. Molecular characterization of Beauveria brongniartii isolates obtained from Melolontha melolontha in Valle d'Aosta (Italy) by RAPD-PCR. Letters in Applied Microbiology, v.26, p.317-324, 1998.

PONTECORVO, G.; ROPER, J.A.; HEMMONS, L.M.; MacDONALDS, K.D.; BUFTON, A. W.J. The genetics of Aspergillus nidulans. Advances in Genetics, v.5, p.141-148, 1953.

ROHLF, F.J. NTSYS-pc: numerical taxonomy and multivariant analysis system; version 1.80. Setauket: Exeter Publishing, 1994.

SOSA-GÓMEZ, D.R. Coleção de fungos entomopatogênicos: catálogo de isolados. Londrina: EMBRAPA, CNPso, 1998. 38p.

SNEATH, P.H.A; SOKAL, R.R. Numerical taxonomy. San Francisco: Freeman, 1973.

TIGANO-MILANI, M.S.; GOMES, A.C.M.M.; SOBRAL, B.W.S. Genetic variability among Brazilian isolates of the entomopathogenic fungus Metarhizium anisopliae. Journal of Invertebrate Pathology, v.65, p.206-210, 1995a.

TIGANO-MILANI, M.S.; HONEUCUTT, R.J.; LACEY, L.A.; ASSIS, R.; MCCLELLAND, M.; SOBRAL, B.W.S. Genetic variability of Paecilomyces fumosoroseus isolates revealed by molecular markers. Journal of Invertebrate Pathology, v.65, p.274-282, 1995b.

VIDAL, C.; LACEY, L.A.; FARGUES, J. Pathogenicity of Paecilomyces fumosoroseus (Deuteromycotina: Hyphomycetes) against Bemisia argentifolii (Homoptera: Aleyrodidae) with a description of a biossay method. Journal of Economic Entomology, v.90, p.765-772, 1997.

WILLIAMS, J.G.K.; KUBELIK, A.R.; LIVAK, K.J.; RAFALSKI, J.A.; TINGEY, S.V. DNA polymorphisms amplified by arbitrary primers. Nucleics Acids Research, v.18, p.6531-6535, 1990.

WRAIGHT, S.P.; CARRUTHERS, R.I.; BRADLEY, C.A.; JARONSKI, S.T.; LACEY, L. A.; WOOD, P.; GALAINIWRAIGHT, S. Pathogenicity of the entomopathogenic fungi Paecilomyces spp.. and Beauveria bassiana against the silverleaf whitefly, Bemisia argentifolii. Journal of Invertebrate Pathology, v.71, p.217-226, 1998.

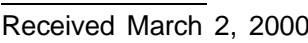

